\title{
Maternal Bias of Immunity to Her Offspring: Possibility of an Autoimmunity Twist out from Maternal Immunity to Her Young
}

\author{
Nobuo Yamaguchi, ${ }^{1,2}$, Takafumi Takei ${ }^{2}$, Rui Chen ${ }^{3}$, Palidan Wushuer ${ }^{4}$, Wen Hsin $\mathrm{Wu}^{5}$ \\ ${ }^{1}$ Department of Serology, Kanazawa Medical University, Uchinada, Japan; ${ }^{2}$ Ishikawa Natural Medicinal Products Research Center \\ Foundation, Fukubatake, Kanazawa, Japan; ${ }^{3}$ Tongji Medical College, Huazhong University of Science and Technology, Wuhan, \\ China; ${ }^{4}$ Xinjiang Medical University affiliated hospital of traditional Chinese Medicine, Urumqi City, China; ${ }^{5}$ Taipei Medical Uni- \\ versity, Medical School, College of Medicine, Taipei City, Taiwan. \\ Email: serumaya@kanazawa-med.ac.jp
}

Received October $15^{\text {th }}, 2012$; revised November $17^{\text {th }}, 2012$; accepted November $28^{\text {th }}, 2012$

\begin{abstract}
The major interest in materno-foetal relation is why fetus is not rejected by the mother, even in a different genetic background. But in this article we have been investigating about the effect(s) of maternal antigenic stimulation or infection upon the active immune responses in her offspring. The results of various researchers have certainly pose significant problems as to the defense of infants against infectious agents, especially those introduced by their mothers. But we have already reported that maternal antigenic stimulation greatly suppresses the specific immune response of the offspring in a system of mouse vs heterologous erythrocytes and other T-dependent antigens. This suppression was antigen specific and effective on 1/6 life of rodents. The mechanisms that concerned in this suppression were not antigen administered nor antibody produced in the mother. The supporting evidences were that this suppression was MHC restricted and limited in during pregnancy for induction between mother and her young. The system examined was separating genetic backgrounds that the haplotype was different in F2 family where half of the young were identical but not in remainder to the F1 mother mouse. From this backcross system, this suppression was MHC restricted, suggesting cell to cell contact with mother to her young. Moreover, cytokine level in both mother and her young, IFN- $\gamma$ levels was up-regulated in such a young whose mother was immunized with antigen. The significance of this phenomenon were accessed as biological and medical intervention especially for the mother and infant health care and prevention of hypersensitivities, autoimmune syndrome for her young after delivery.
\end{abstract}

Keywords: Pregnancy; Materno-Foetal Relation; Maternal Bias of Immunity; Active Immune Suppression; MHC Restricted Suppression; Lymphocyte Trafficking; Micro Chimerism; Morning Sickness

\section{Introduction}

The currently held view of the immune system proposes generally acceptable description supported by evidence. There are two primary systems, innate and adaptive Despite this defense system the overwhelming problems of possessing this dual system, the innate and adoptive does not seem to guard or even prevent the development of one internal threat to survival, but direct to autoimmunity accompanying hypersensitivity.

Materno-foetal relations include various aspect of immunological affair connected to the development of immunological maturation to her young. The one of the major interests in materno-foetal relations is how the fetuses can be delivered in safe from the uterus in the immunologically risky environment. The other is what kind of effect of mother dealt with to her baby's immune ca- pability after delivery.

The most important merit from mother was published by many researchers about the transferable immuno-globulins via uterus and/or her milk. These reported effects were revealed when an infectious immunity are necessary to the agents invaded to the baby.

This was the case in many species of mammals and at least half a year was effective to protect in human.

In the course of our line of studies, we confirm the new expansion of biological movement were the case between mother and her young with a neat mice system. The our effect was limited period of pregnancy not by transferable mother antibody but more biologically significant system including immunological factors.

In this review, we employed genetically identical mouse system and try to understand the significance as 
biological system in order to understand the fundamental effect of mother to her young. During pregnancy we try to access the immune capability of mother mice employing a clear system of MHC expression and try to establish a preventive combination of gamates for future succeed of the progeny [1-6]. In this review, we would like to introduce the materno-foetal relations employing simple genetical background of MHC complex, This stand point of view promise to the safe delivery and safe growth of baby's life without autoimmunity and hypersensitivity. Moreover this trial may pilot a safe combination of marriage to prevent so called morning sickness in pregnant mothers. In general an aspect to the ontogeny of immune capability, the pregnant status is the critical time to start the ontogeny of the immune system under the genetically non-identical combination of her spouse, gene circumstance from mother and father. The introduction of new genes is important not only in the reproduction of the population but also in the limiting value of the litter size. Maintenance of mother is important in biological aspect essential for the future to develop fetuses in uterus who can not develop without mother, large enough to rest her/his uterus. The size of the fetus became bigger in homologous relations than in hetrologous ones [7-11]. In these situation, maternal cytotoxicity against to the fetus is induced only when genetic background as in MHC and minor $\mathrm{HC}$ is different. The development of immune system in young is attacked and modified under the influence of maternal immunological attack. In this article, we tried to know first when genetic background is identical in mother and her young, how is mother affect to the fetus [12-15]. The immunological intervention through the mother to the fetuses is a concern even in homologous as well as heterologous relations but the quality and the quantity may different [16-25]. Our interest is to focus on the acquired immunological effect of the mother to her young in an environment free from allogeneic effects, To avoid transplantation immunity resulted in allogenic relations in mother and her young, syngeneic and specific-pathogen free animals were employed $[12,26]$. In our experimental system, maternal antibodies were transferred via the placenta and/or milk, suggesting that a mixed level of serum antibodies were in the peripheral serum [12]. In young mice, by using a conventional method to detect antibody levels, it is difficult to distinguish whether the origin of antibody molecules derived from the mother or her young $[1,12,13]$. Therefore we employed a tentative method to detect active production of specific antibodies in the offspring using localized hemolysis in a gel assay originated and modified by Jerne $[27,28]$. Using this method, sheep erythrocyte is famous for its antigenicity of T-dependent antigen and convenience for use in laboratory treatments. Ovalbumin was also employed as T-dependent antigen but soluble type of them that easy to introduce tolerance when it was used without adjuvant. We also selected bacterial lipopolysaccharide (LPS) and bacterial polymelised flagellin as T-independent antigen for this experimental system [29].

We have already reported that maternal antigenic stimulation greatly suppresses the specific immune response of the offspring in a system of mouse vs. heterologous erythrocytes. But some reports showed that the immure responses in young were augmented as a results of maternal immunity $[17,18,20]$. As to a possible mechanism for inducing this suppression, it is generally suggested that antigen molecules or specific antibodies are transmitted from the mother to her offspring, and neonatal tolerance may be induced. In order to confirm this possibility, the soluble protein antigen ovalbumin (OVA), with or without adjuvant, was administered to pregnant mice $[12,26]$. First, the immune responses of the groups of mother mice given OVA with or without adjuvant were identified, and then the immune responses of the two groups of the young were compared. Furthermore, the dosage effect of antigen or antisera given to pregnant mice was investigated with respect to the passive effect of immune response in their young. Based on the results thus obtained, a possible mechanism is discussed for the suppression of the immune response in the young, derived from mice stimulated with sheep erythrocytes (SRBC) and OVA with or without adjuvant $[12$, 26].

\section{Experimental Model in T-Dependent Ag}

\subsection{SRBC as Antigen}

\subsubsection{The Immune Status of Mother Mice and the Suppression in the Young}

Pregnant C57BL/6 mice were immunized with sheep red blood cells, $\left(2 \times 10^{8} /\right.$ mouse $)$ on day 10 of gestation. The mother mice induced maximum primary responses to SRBC at this amount of Ag, the offspring were then delivered and raised until they were young adults after which each group was immunized with an optimum amount of corresponding antigen. Even in such infant, 2week-old mice, the response was good at about $80 \%$ in the maximum number of plague-forming cells (PFC)/active antibody production in the normal control group [13]. However, in the experimental group whose mothers had been immunized with SRBC during pregnancy, these responses were completely suppressed, up to 20 weeks of age (1/6 of life span in rodent, Figure 1). The young possessed, however, a significant amount of serum antibodies to SRBC suggesting transfer from the mother [13]. To ascertain the effect of dosage on the relationship be- 


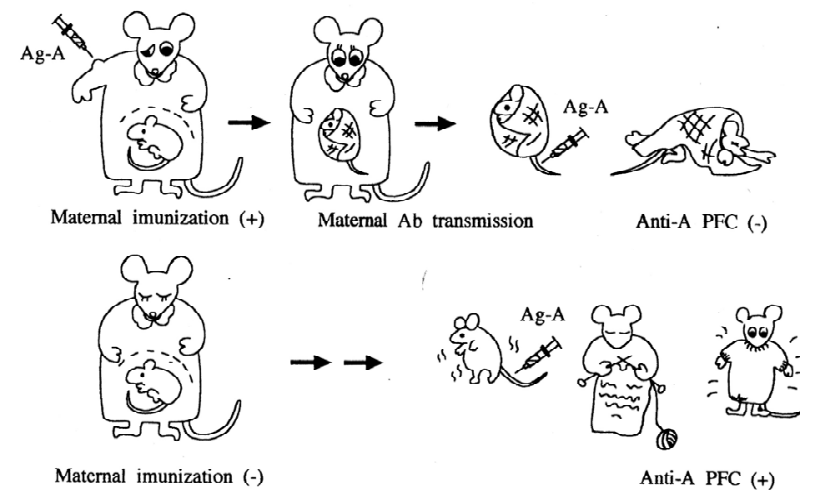

Figure 1. Effect of maternal antigenic stimulation on the active immune responses in her young-diagram for experimental system.

tween the immune reactivity of mother mice and the specific immune suppression of their young, various amounts of erythrocytes were intraperitoneally injected into pregnant mice. When pregnant mice were stimulated with $10^{8}$, $10^{9}$ and $10^{10}$ SRBC, they produced a significant number of PFC by themselves, but in such young, the active immune responses of their offspring were completely suppressed (Figure 2, [13]). When pregnant mice were stimulated with small amounts of SRBC (less then $10^{7}$ ), they did not induce PFC, but the specific PFC development in the offspring from such mother mice was not completely suppressed.

Pregnant mother mice were divided into two groups, the one was received antigenic stimulation (experimental group) and the other was not (control group). Both groups of the young mice were brought up to $6-8$ weeks and then immunized with optimal amount of the corresponding antigens. The active antibody production was then detected by elegant but old-fashioned method socalled localized hemolysis in gel (or plaque forming cell; PFC). After the antigenic stimulation, the experimental group did not respond to produce corresponding antibody, but the control group produce antibody forming cell that secret specific antibodies. This was the standard protocol of for accessing the maternal effect during pregnancy.

After preparing the pregnant mice, various doses of antigen were administered via abdominal. 6 - 8 weeks later, their offspring were challenged to induce active immune response to heterologous RBC.

\subsubsection{An Effective Time for the Antigenic Stimulation of the Mother Mice}

In order to avoid the possibility of antigen transfer from mother to her embryo for this suppression, various stage of pregnant mouse were prepared and the active immune response was tested to the each offspring. The mother mice were line up from three day before fertilization to one day before delivery. In such mothers were administered optimal amount of antigen and all her young were immunized with corresponding antigen. As a result of this trial, both mother three days before fertilization and one day before delivery did not induce suppression in her young. These results indicated that antibody production process ant antigen itself were important to induce suppression in her young.

During the preparation for the pregnant mother, various stage of mother mice were administered antigen via abdominal. 6 - 8 weeks later, their offspring were challenged to induce active immune response to heterologous $\mathrm{RBC}$ (Figure 3).

\subsection{Ovalbumin as Antigen and the Effect of Adjuvant}

It has been reported that a soluble protein antigen was a good inducer of suppressor cells especially when injected with high or low doses without adjuvant $[12,26,30]$. However in such antigen, it is possible to access the active antibody production by plaque-forming cell (PFC)

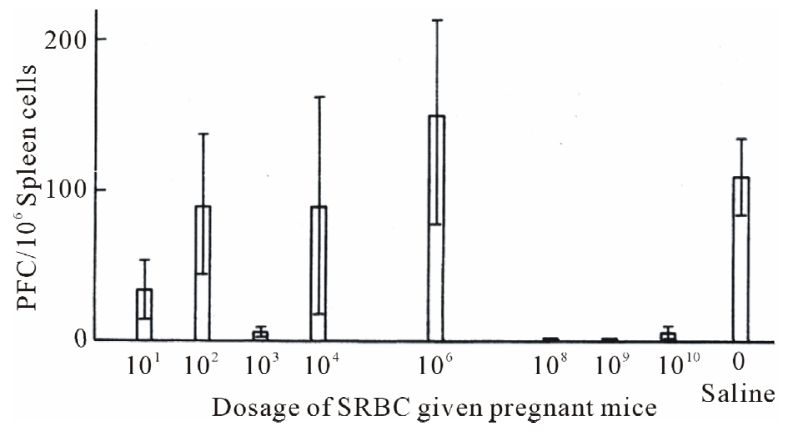

Figure 2. Effect of maternal antigenic stimulation on the active immune responses in her young-antigen amount for mother for induce the suppression.

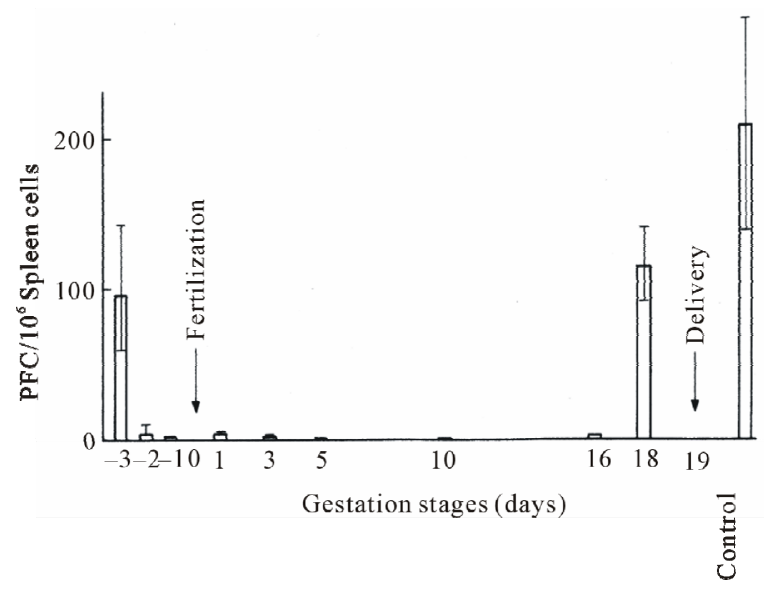

Figure 3. Effect of Maternal antigenic stimulation on the active immune responses in her young-the pregnant stage and the administration of antigen to the mother mice. 
[31]. Under such a condition, there may be some factor in the suppressor cells that is transmitted from the mother mouse and establishes suppression in the young [32]. To test this possibility, pregnant mice were stimulated with large dosage $/ 2 \mathrm{mg}$ of soluble OVA without adjuvant in order to confirm the development of suppressive $\mathrm{T}$ cells in these mice $[2,3,33]$. Contrary to our expectations, the offspring responded normally after immunization with OVA $6-8$ weeks after birth. However when pregnant mice were positively stimulated by OVA and the adjuvant $\mathrm{Al}(\mathrm{OH})_{3}$, these offspring more effectively suppressed PFC development [26]. So it is concluded that this suppression simply affected maternal immune status. Rather, this suppression was well established when the mother mice was respond to antibody formation.

\subsection{Effect of Passively Transmitted Antiserum on the Pregnant Mice}

The former experiment showed that only offspring from mothers stimulated with a large amount of SRBC were able to suppress the development of specific PFC.

The data suggested that maternal transmitted antibodies to their young suppressed or discharged subsequent antigenic stimulation. To test this possibility, pregnantmice were injected with a specific antiserum via the tail vein once or several times during gestation. The antiserum was collected from the same strain of mice which was immunized with $1 \times 10^{8}$ SRBC twice at an interval of 3 weeks. The titer of anti-SRBC level was as high as 1:1024. The control group was injected with a normal serum from the same strain of mice. The offspring were kept in an environment free from specific pathogens for 6 weeks after delivery. The offspring from mice injected with the antiserum during pregnancy showed only a slight suppression that was almost the same as that of the offspring from the control group [30,31].

From our preliminary examination, anti-OVA PFC were only detected by injecting an antigen in the form of $\mathrm{Al}(\mathrm{OH})_{3}$ gel twice at an interval of 2 weeks (the first with $200 \mu \mathrm{g}$ and the second $20 \mu \mathrm{g}$ ). A single shot of OVA with adjuvant did not induce anti-OVA PFC. To test the effect of the different immune status of mother mice (especially PFC induction) on the induction of PFC suppression in their offspring, pregnant mice received primary stimulation from OVA with adjuvant, and were divided into two groups. One group received the booster and the other did not (the control group). The suppression of PFC development was not as strong in the offspring of mother mice who received a booster with the same antigen compared with that from the control group.

Together with the former data, these results suggest that some factors of the positive immune state of pregnant mice induced suppression of the immune response in their young.

\section{Adoptive Transfer of Ab or Ag}

The above result implied in part that transferred serum $\mathrm{Ab}$ suppressed the active response of the offspring $[17,18,20,32]$. In order to test this effect of the passive transfer of antibodies, high titer of anti-SRBC, polyclonal antibodies or monoclonal IgG antibodies were injected via the tail vein of mice in their 10 day of pregnancy. The 6-week old offspring were then actively immunized with SRBC and developed PFC 5 days later. The experimental groups developed PFC at a slight lower rate $(83 \%)$, but remained within the normal response range. The specific antibody transfer experiment showed a slight depression in the active PFC responses, but complete suppression of PFC response was not induced in the offspring whose mothers were passively injected neither polyclonal or monoclonal specific $\mathrm{Ab}[33,34]$.

We then tested the effect of antigen leakage form the mother to the fetus, in order to understand the induction of neonatal tolerance of the acquired immune response is the case or not in this system [30,35]. Ovalbumin is a protein antigen that was tolerogenic itself, but became immunogenic when injected with the appropriate adjuvant. When BALB/C mice, which have a high responder to OVA were immunized with low to high doses of OVA without adjuvant, none of the mother mice responded to anti-OVA PFC even a after following an optimal OVA administration plus adjuvant. In the case of a high dose of OVA challenge without adjuvant to the mother mice, it is possible that an antigen molecule split off to the fetus and may have induced neonatal tolerance [35-37]. But in such a case, the offspring responded to anti-OVA PFC after delivery. On the other hand, when the mother mice were immunized with OVA antigen plus adjuvant, immunological memory was induced in the mother mice but the young did not respond following OVA antigen even if it included adjuvant. These results showed that an antigen fragment in the mother did not induce this suppression [4].

\section{Foster Mother Experiment}

Employing more natural system to test the transfer of antigen or antibody the foster mother experiments were designated. Pregnant mice were selected according to age and stage of pregnancy and divided into two groups. One group received antigenic stimulation and the other did not. On the day of birth, the young of both group were exchanged each other. Five weeks after delivery all the mice were antigenically stimulated by an optimal amount of SRBC. The results are as follows: the offspring nursed by the normal control mothers but delivered by the ex- 
perimental mothers did not respond to further SRBC stimulation. On the other hand, the offspring nursed by the experimental mother but delivered by the normal mother responded well to further SRBC stimulation. Even when they possessed the passive transferred specific antibody, it did not affect this suppression [4] (Figure 4).

During the preparation for the pregnant mother, almost same stage of pregnant mothers was divided in to two groups. The one group was administered RBC (experimental group) and other was only physiological saline (control group). The two group of baby mice were mutually exchanged and brought up to 8 weeks. And then active antigen stimulation was carried out for each group of mice.

\section{Adoptive Transfer of Effector Cells in This Suppression}

Immune suppression is usually attributed to CD8 positive or so called suppressor cells [38-46]. In this suppression system, the effector cells were identified by the adoptive transfer system. This experiment was carried out in both the mother mouse and her offspring by preparing splenic nucleated cells separating into macrophages, $T$ cells and $\mathrm{B}$ cells. The $\mathrm{T}$ cell population was further divided into
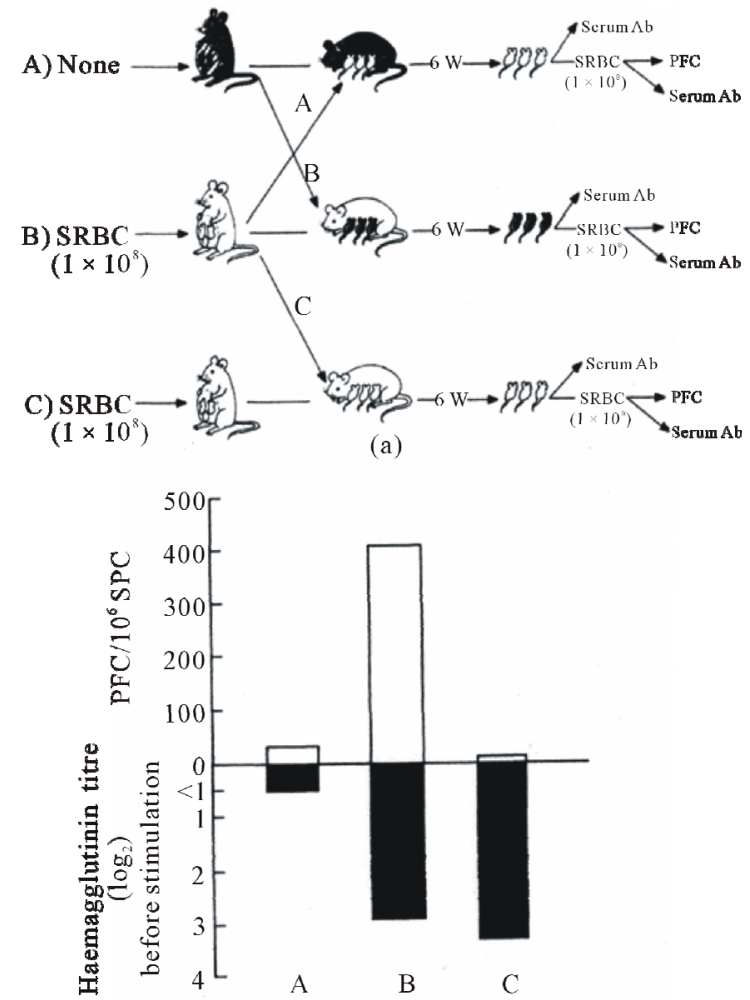

(b)

Figure 4. Effect of Maternal antigenic stimulation on the active immune responses in her young - the foster mother experiment between experimental and normal group.
CD4 and CD8 cells. Each cell suspension in offspring was adjusted from $1 \times 10^{3}$ to $1 \times 10^{7} / 0.2 \mathrm{ml}$ and adoptively transferred into the young normal mice via the tail vein.

The cell population analysis of her young showed that $T$ cell populations were effector cells but macrophage or $\mathrm{B}$ cells was not [41]. A further population analysis of the materno-foetal system demonstrated that $\mathrm{CD} 4$ but not CD8 cells were effector cells for this type of suppression $[14,47]$. When young mice as a donors for the cell transfer, there were few reports of CD4 cells as effector cells for suppression [48-51]. The case for this suppression is that when we processed conventional cell analyses in SRBC-immunized mice that were the same age as the control young, the CD8 but not CD4 cells suppressed further antigenic stimulation in our laboratory as usually expected [43-46,52-54].

\section{Maternal Immunization and Adoptive Transfer of Lymphoid Cells}

\subsection{Normal Pregnant Mice Were Administered Cell Derived from the Immunized Pregnant Mice}

The results show the basic schedules for maternal immunization of pregnant mice and PFC assay in the offspring. When the pregnant female mouse had been immunized intraperitoneally with $2 \times 10^{8} \mathrm{SRBC}$, the production of anti-SRBC PFC in the offspring was completely suppressed. To determine which maternal lymphoid cells were responsible for this suppression of anti-SRBC PFC responses, adoptive transfer experiments were carried out also in mother. Pregnant female mice were injected intraperitoneally with $2 \times 10^{8} \mathrm{SRBC}$ on day 10 of gestation. Five or 6 days after the injection, the maternal peritoneal exhadate cell; PEC or SPC were transferred into other non-immunized pregnant mice on day 10-13 of gestation. The offspring of the recipient pregnant mice were raised for about 6 weeks and tested for their anti-SRBC PFC responses. Suppression was observed in the IgG PFC only when the recipient mice received $10^{4}$ or more SPC from the immunized pregnant mice. A dose of $10^{6} \mathrm{SPC}$ yielded similar results in other experiments [one example is as follows: $1067 \pm 64$ IgM PFC and $194 \pm 25$ IgG$\mathrm{PFC} / 106 \mathrm{SPC}$ in the offspring of the normal pregnant mouse $(\mathrm{n}=5), 1107 \pm 110 \mathrm{IgM}$ PFC and $56 \pm 22$ IgG$\mathrm{PFC} / 106 \mathrm{SPC}$ in the offspring of the recipient mouse $(\mathrm{n}=$ 7); $0.001<\mathrm{p}<0.01$ in IgG PFC]. For the maternal PEC of the immunized pregnant mice, the same experiments were carried out and similar results were obtained. Furthermore, the maternal cells of the immunized pregnant mice were separated into $T$ cells, B cells and macrophages, and transferred to other normal pregnant mice. 
Thus a pregnant female mouse was injected intraperitoneally with $2 \times 10^{8} \mathrm{SRBC}$ on day 10 of gestation. Five or 6 days after injection, the maternal PEC or SPC was obtained from the pregnant mouse. The maternal SPC or PEC of immunized pregnant mice were separated into $T$ cells, B cells and macrophages. Each type of maternal cell was transferred intravenously into other non-immunized pregnant females on days 10-13 of gestation. The offspring of the recipient pregnant mice were raised for about 6 weeks and tested for their anti-SRBC PFC production. The data shows the results in offspring of the pregnant mice that had received $\mathrm{T}$ cells, B cells and macrophages separated from the maternal PFC of the immunized pregnant mouse. The suppression of antiSRBC PFC was observed only in the offspring of the recipient pregnant mice that had received $\mathrm{T}$ cells of the immunized pregnant mice by adoptive transfer. Such suppression was not observed in offspring from the recipient pregnant mice that had received other types of cells. Thus neither maternal B cells nor macrophages induced the suppression of PFC responses in the offspring of the recipients. With the dosage experiment, we tried to titrate the maternal $\mathrm{T}$ cells obtained from the SPC of the immunized mouse. $5 \times 10^{3}$ or more maternal $\mathrm{T}$ cells were required to obtain a suppressive effect on the PFC responses in the offspring, no such effect was observed with lower doses [14]. In other experiments, maternal B cells were obtained from the SPC of the $2 \times 10^{8}$ SRBC immunized pregnant mice and then transferred into the normal pregnant mice at the dose $2 \times 10^{4}$ according to the same procedure. One example of the results is as follows: $521 \pm 71 \mathrm{IgM}$ PFC and $190 \pm 60 \mathrm{IgG}$ PFC, $174 \pm 29 \operatorname{IgG}$ PFC $(n=9)$ in offspring of the normal pregnant mouse. No suppression was observed in the experiments of B-cell transfer. These results showed that the maternal $\mathrm{T}$ cells of immunized pregnant mice are predominantly responsible for the suppression of PFC responses in offspring.

\subsection{Maternal T-Cell Subsets}

We also investigated which subsets of the maternal $\mathrm{T}$ cells were responsible for the suppression of PFC production in offspring. The pregnant mouse was intraperitoneally immunized with the same dose of SRBC as above on day 10 of gestation. On the day 6 after immunization, nylon wool-purified $\mathrm{T}$ cells were obtained from the maternal spleen cells and separated into populations of maternal L3T4-depleted T cells, maternal Lyt-22-depleted T cells and whole T cells. Each population of $\mathrm{T}$ cells was adoptively transferred into other normal pregnant mice in the same way. The production of antiSRBC PFC was examined in offspring of the recipient pregnant mice in the same way as described above. No suppression of anti-SRBC PFC was observed in the offspring of the recipient pregnant mouse into which the L3T4-delpeted T cells had been transferred. On the other hand, suppression of PFC was observed in the offspring of the recipient pregnant mice into which the maternal Lyt-2-2-depleted $\mathrm{T}$ cells or population of whole maternal $\mathrm{T}$ cells had been transferred, suggesting that the maternal $\mathrm{L} 3 \mathrm{~T}^{+} \mathrm{T}$ cells are responsible for the immune suppression induced by maternal immunization.

These effector population analysis in both mother and her young, showed that CD4 (Lyt2-2 depleted) cells were key cells for this suppression. But these cell populations its self did not suppressed anti-SRBC PFC when injected into the immunized individuals [14].

\subsection{Maternal T cells Induce Suppression of PFC Response in Offspring in an MHC-Restricted Fashion}

Above experiments implied the same subtype of $\mathrm{T}$ cells were effector cells in both mother and her young. Moreover maternal cell may difficult to cross the anatomical barrier between mother to her young. Many reports concerned about immunological suppression, how the direct contact were inportant in the cellular cooperation [15, 55-72]. The mechanism of suppression still unclear so as to test the interaction of mother and her young, next we tried to test MHC-restriction is fact in this suppression or not [6,29-37].

C57BL/6J $(\mathrm{H}-2 \mathrm{~b})$ pregnant mice were intraperitoneally injected with $2 \times 10^{8} \mathrm{SRBC} /$ mouse on day $10-12$ of gestation. Five days later, maternal $\mathrm{T}$ cells were obtained from the spleen of the immunized pregnant mouse and were adoptively transferred into the normal pregnant mice of $(\mathrm{C} 3 \mathrm{H} / \mathrm{HeJ} \times \mathrm{C} 57 \mathrm{BJ} / 6 \mathrm{~J}) \mathrm{F}_{1}$ on day $10-12$ of gestation. The recipient mice had been back crossed with $\mathrm{C} 3 \mathrm{H} / \mathrm{HeJ}$ male mice. Accordingly, the $\mathrm{H}-2$ haplotype expressed in the offspring was $\mathrm{H}-2^{\mathrm{b} / \mathrm{b}}$ and $/$ or $\mathrm{H}-2^{\mathrm{b} / \mathrm{k}}$. they were raised for 6 weeks and then examined for the production of anti-SRBC PFC. Suppression of the antiSRBC IgG-PFC responses was detected only in the offspring of $\mathrm{H}-2^{\mathrm{b} \times \mathrm{k}}$ but not in $\mathrm{H}-2^{\mathrm{b} \times \mathrm{b}}$. In this experiment, the controls groups were the offspring of the $\mathrm{F}_{1}$ pregnant mice that had been back-crossed with the $\mathrm{C} 3 \mathrm{H} / \mathrm{HeJ}$ male mice. The PFC responses were compared between the controls and the offspring of the recipient with the same haplotype. Reverse results were obtained in a reverse back-cross mating pattern [15]. Then $\mathrm{C} 3 \mathrm{H} / \mathrm{HeJ}$ pregnant mice were intraperitoneally injected with $\mathrm{SRBC}$ on days 10-12 of gestation. Five days later, the maternal $\mathrm{T}$ cells were obtained from the spleen of the immunized pregnant mouse and adoptively transferred into $(\mathrm{C} 3 \mathrm{H} / \mathrm{HeJ} \times$ $\mathrm{C} 57 \mathrm{BL} / 6 \mathrm{~J}) \mathrm{F}_{1}$ pregnant mice that had been back-crossed with $\mathrm{C} 57 \mathrm{BL} / 6 \mathrm{~J}$ male mice. The suppression of anti- 
SRBC PFC responses was found only in the $\mathrm{H}-2^{\mathrm{b} \times \mathrm{k}}$ offspring among $(\mathrm{C} 3 \mathrm{H} / \mathrm{HeJ} \times \mathrm{C} 57 \mathrm{BL} / 6 \mathrm{~J}) \mathrm{F}_{1} \times \mathrm{C} 57 \mathrm{BL} / 6 \mathrm{~J}$ from $(\mathrm{C} 3 \mathrm{H} / \mathrm{HeJ} \times \mathrm{C} 57 \mathrm{BL} / 6 \mathrm{~J}) \mathrm{F}_{1}$ recipients [15].

\subsection{Maternal T Cells Generate a Repertoire of Suppressor $\mathrm{T}$ Cells in the Offspring}

So as to test the above in vivo MHC-restriction between mother and her young in vitro, PFC development and blastogenic responses [9-11] were induced in plastic dishes that were mixed with antigen presenting cells, $\mathrm{T}$ and $\mathrm{B}$ cell Combination with the cells from mother and her young.

A C3H/HeJ pregnant mouse was intraperitoneally injected with $2 \times 10^{8}$ of SRBC on day 12 of gestation. Maternal $\mathrm{T}$ cells were obtained from SPC of the immunized pregnant mouse 5 days after injection, and intravenously transferred at $2 \times 10^{4}$ cells/mouse into $(\mathrm{C} 3 \mathrm{H} / \mathrm{HeJ} \times$ $\mathrm{C} 57 \mathrm{BL} / 6 \mathrm{~J}) \mathrm{F}_{1}$ offspring on day 10 of gestation. The offspring of these recipients were raised for more than 6 weeks. This maternal T-cell population had induced the suppression of anti-SRBC IgG-PFC in the offspring with MHC restriction [14]. The $F_{1}$ offspring of the recipients were examined with respect to the MHC restriction of suppressor activity. $\mathrm{T}$ cells $\left(\mathrm{T}_{\text {off }}\right)$ of one $(\mathrm{C} 3 \mathrm{H} / \mathrm{HeJ} \times$ $\mathrm{C} 56 \mathrm{BL} / 6 \mathrm{~J}) \mathrm{F}_{1}$ offspring from the recipient, Th of $(\mathrm{C} 3 \mathrm{H} / \mathrm{HeJ}$ $\times \mathrm{C} 56 \mathrm{BL} / 6 \mathrm{~J}) \mathrm{F}_{1}$ and $\mathrm{B}$ plus accessory cells from $\mathrm{C} 3 \mathrm{H} / \mathrm{HeJ}$ and $\mathrm{C} 57 \mathrm{BL} / 6 \mathrm{~J}$ were obtained. In this experimental scheme, $T_{\text {off }}$ and $T h$ were enriched with nylon wool column and purified by treatment with anti Ia mAb and $\mathrm{C}^{\prime}$. $\mathrm{T}_{\text {off }}$ were cultured with $2 \times 10^{6}$ cells of Th, $5 \times 10^{6} \mathrm{SRBC}$ primed $\mathrm{B}$ plus accessory cells from $\mathrm{C} 3 \mathrm{H} / \mathrm{HeJ}$ or $\mathrm{C} 57 \mathrm{BL} /$ $6 \mathrm{~J}$ mice and $10^{8} \mathrm{SRBC}$. One example is shown as following, $\mathrm{T}_{\text {off }}$ suppressed the anti-SRBC PFC responses by the $\mathrm{C} 3 \mathrm{H} / \mathrm{HeJ}$-derived $\mathrm{B}$ plus accessory cells but not C57BL/6J-derived ones. In order to confirm these results, a similar experiment was carried out in the reverse crossmating pattern with adoptive transfer [15]. In the reverse experiment, suppression was observed in the opposite direction. $\mathrm{T}_{\text {off, }}$, which were obtained from offspring of C57BL/6J recipients, suppressed the anti-SRBC PFC responses by the $\mathrm{C} 57 \mathrm{BL} / 6 \mathrm{~J}$-derived $\mathrm{B}$ plus accessory cells. These results suggest that the suppressor $\mathrm{T}$ cells among the $\mathrm{T}_{\text {off }}$ population were activated only when SRBC antigens were present and recognized in the context of the same MHC haplotype as the one utilized in the maternal T-cell responses of immunized pregnant mice (Figure 5).

Additionally, in the mating pattern, we examined whether the suppressive factor produced by $\mathrm{T}_{\text {off }}$ was restricted to MHC in the same fashion as described above. To test this idea, nylon wool-passed $\mathrm{T}_{\text {off }}$ and Th were purified by treatment with anti- $\mu$ chain $\mathrm{mAb}$ and $\mathrm{C}^{\prime}$. Un-

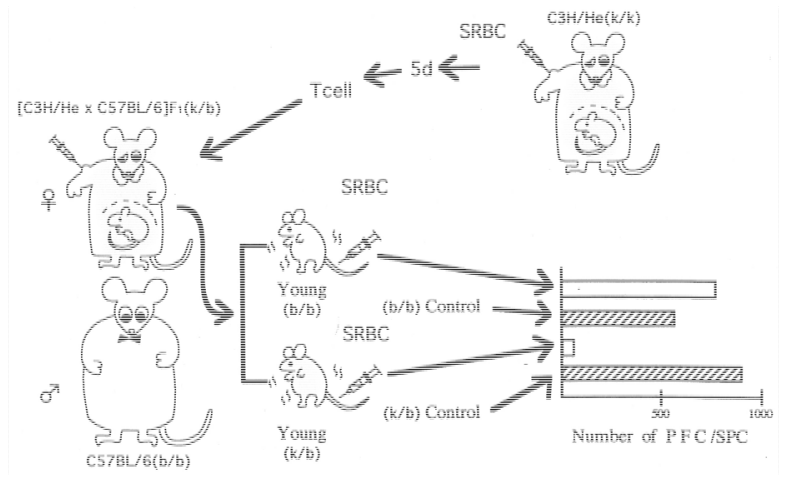

Figure 5. This suppression exhibited by MHC restricted fashion. This figure showed the experimental protocol and results brought by special back crossing with syngeneic pure strain of mice.

der this condition, antigen-presenting cells (APC) and macrophages, of $\mathrm{H}-2^{\mathrm{b} \times \mathrm{k}}$ were present in the $\mathrm{T}_{\text {off }}$ and $\mathrm{Th}$ populations. Accordingly, $\mathrm{T}_{\text {off }}$ should have recognized SRBC antigens that were present in association with the $\mathrm{k}$ haplotype of MHC utilized by maternal $\mathrm{T}$ cells of immunized pregnant mice. $\mathrm{T}_{\text {off }}$ including $\mathrm{H}-2^{\mathrm{b} \times \mathrm{k}}$ APC suppressed the anti-SRBC PFC production, particularly IgG-PFC, by both C57BL/6J-derived and $\mathrm{C} 3 \mathrm{H} / \mathrm{HeJ}$-derived B plus accessory cells [15]. These observations show the suppressive factors produced by suppressor $\mathrm{T}_{\text {off }}$ function without MHC restriction.

\section{MHC Class II Knockout Mouse}

In former experiment, MHC restriction was evidenced by specially cross-mating mice system. In this section, using MHC class II knock out mouse was employ to see whether MHC class II molecule are major concern this suppression or not [70,72-73]. Male C57BL/6 mice that was modified the gene for express class II molecule I-A-1- were mated with B10. BR $\left(\mathrm{H}-2^{\mathrm{k} / \mathrm{k}}\right)$ female mouse, made F1 mouse (I-A $\left.\mathrm{A}^{\mathrm{b}-/ \mathrm{k}+}\right)$. F1 male was then mating another conventional F1 I-A ${ }^{\left(\mathrm{b}+\mathrm{k}^{+}\right)}$female mouse, made on F2 family consisted with $(\mathrm{b}+/-),(\mathrm{b}-/ \mathrm{k}+),(\mathrm{b}+/ \mathrm{k}+)$ and $(\mathrm{k}+/ \mathrm{k}+)$ young. $\mathrm{F} 1$ female mouse was stimulated SRBC and then her offspring were stimulated F1 gene. PFC responses were shown in the Figure and Table, indicating PFC response were suppressed in the offspring that was matched with MHC class II type but not in MHC class II knock-out young. This result also showed that the MHC class II molecule was important for establishing this suppression [74].

\section{Cytokine Production in Mother and Her Offspring}

As previously reported when pregnant $\mathrm{C} 57 \mathrm{BL} / 6 \mathrm{~J}$ mice were injected with SRBC on the 12th day of gestation, 
their subsequent offspring showed a marked inhibition of antibody formation to the SRBC antigens after they were immunized.

The antibody response as determined using a modified Jerne, Nordin assay to detect IgM antibody forming cells (PFC) was measured four days after immunization in 6 week old mice and was compared to age matched controls. The data clearly show that there is a significant inhibition of the humoral immune response in these young mice. However, when cell mediated or delayed type hypersensitivity was determined in analogous young mice, much different results were obtained. The foot pad swellling assay was used to assay the DTH response of the young mice. Rather than a decrease in immunity as seen in the humoral response, there was either no change or a suggestion of an increased level of cell mediated immunity in the young mice born to the immunized mothers. Therefore it was of interest to determine the function of the $T$ cells from the mothers and their offspring in terms of their ability to control the manifestations of cellular and humoral immunity.

Pregnant C57Bl/6J mice were injected with SRBC i.p. at the 12 day of gestation. Subsequent offspring at 6 weeks of age were injected with SRBC i.p. Two to three weeks later, splenic $\mathrm{T}$ cells from the offspring of immunized mothers, were cultured with syngeneic antigen presenting cells (in vitro primed APC) for 4 days. Then, both the proliferative ability of the T cells and the levels of cytokine production in the cultures were examined. These experiments were designed to determine if there were changes in the $\mathrm{T}$ cell compartment in the young mice which could explain the alterations seen in humoral and cellular immune function. There was no differences seen in the proliferative ability of $\mathrm{T}$ cells from the offspring of immunized mothers as compared to age matched controls. Furthermore there were no differences seen in the profile of cytokine synthesis between the offspring of immunized mothers and age matched controls. IL-2, IL-4, and IFN-r production were not statistically different in a comparison of the results from either group. Splenic $\mathrm{T}$ cells obtained from the spleens of immunized offspring from immunized and non-immunized mothers were also examined for their ability to release certain cytokines in vitro. The cytokines IL-2, IL-4, and IFN-r were measured by the ELISA technique using supernatants of the $\mathrm{T}$ cell cultures initiated four days after immunization of the young mice in vivo. Synthesis of the cytokines IL-2 and IFN-r by the splenic $T$ cells from the offspring of the immunized mothers showed a statistically significant $(\mathrm{p}$ $=0.04$ ) increase when compared to age matched controls. Il-4 levels were not different between the two groups. It has been reported that there are differences in patterns of cytokine synthesis [75-83]. To investigate this point, pre- gnant and non-pregnant mice were injected with SRBC i.p., and four days later, enriched splenic $\mathrm{T}$ cells were obtained and cultured for 4 days accompanying APC and then the levels as IL-4, IL-2, and IFN-r production were determined. The only one of the three cytokines that showed any difference between the pregnant and nonpregnant mouse groups was IL-4. The T cells from the pregnant mice produced significantly higher $(\mathrm{p}<0.04)$ levels of IL-4, while the levels of IL-2 and IFN-r showed no significant differences between the groups.

To test the cytokine levels in both mother and her young, age-matched mother and age-matched young mice were immunized and then accessed the amount of IL-2, IL-4 and IFN-g. Among the cytokine tested in this experiment, IFN-g levels in the young whose mother was immunized with antigen. This result implied that the mechanism of the suppression in the young whose mother was immunized by antigen during pregnancy made functional bias to her young without simple affect by antigen or antibodies through her mother.

\section{Maternal Lymphocyte Trafficking}

The Maternal immunization induced suppression of the active immune response in her young. The mechanisms which was involved in this suppression was not antigen employed or antibody produced in the mother stated above chapter, but CD4 positive cells in both mother and her young. Moreover, this suppression was the case in the relationship that was MHC-identical fashion between mother and her young. MHC restriction in cell to cell interaction is usually cognate interaction system $[68,69]$. In modern biological considerations, cellular size of materials is hard to across the placenta in normal condition. Adler reported that a mother cells could transfer to her fetus and also in the case between fetus to fetus transmission $[84,85]$. Then we tried to test the cell transfer from mother to her young in our experimental system, the combination and MHC type and experimental design was shown in the Figures 6 and 7. We attempt to substantiate the presence of maternal cells in the foetal circulation through the use of molecular techniques. We found that highly polymorphic microsatellite sequence within the class II Eb gene of the $\mathrm{H}-2$ complex is useful for the molecular detection of various H-2 allells. DNA poly-morphic analysis was used for tracking maternal $\mathrm{H}-2$ alleles in the spleen of baby mice. The main procedures involved polymerase chain reaction in amplification and restriction fragment length polymorphysim analysis of the DNA sequence encompassing the H-2 spesicic microsatelitte from genomic DNA of baby mice. The experimental results indicated that maternal $\mathrm{T}$ cell of immunized pregnant mice cross the placenta into the fetus, eventually inducing antigen specific immunological vias/to- 
lerance in her young mice [86-89].

Identification of $\mathrm{H}-2$ haplotypes by PCR amplification and restriction fragment length polymorphism (RFLP) is shown in Figure 6. Lanes 1-5 show the bands before treatment with Fnu4H Iand lanes 6-10, the band after treatment with Fnu4H I. Lanes 1 and 6 show the H-2 ${ }^{\mathrm{b} / \mathrm{b}}$ mouse, lanes 2 and 7 the $\mathrm{H}-2^{\mathrm{k} / \mathrm{k}}$ mouse, lanes 3 and 8 the $\mathrm{H}-2 \mathrm{~d} / \mathrm{d}$ mouse, lanes 4 and 9 the $\mathrm{H}-2^{\mathrm{k} / \mathrm{b}}$ mouse and lanes 5 and 10 the $\mathrm{H}-2^{\mathrm{d} / \mathrm{b}}$ mouse. $\mathrm{M}, 100$-bp DNA ladder size marker (in bp): 2072, 1500, 700, 500, 400, 300, 200, 100 from top to bottom, respectively.

Lanes 1-5 show the bands before treatment with Fnu4H I and lanes 6-10, the bands after treatment with Fnu4H I. Lanes 1 and 6 show the normal mouse $\left(\mathrm{H}-2^{\mathrm{d}}\right.$, tail), lanes 2 and 7 the normal mouse $\left(\mathrm{H}-2^{\mathrm{d} / \mathrm{b}}\right.$, tail). Lanes 3 and 8 the $\mathrm{T}$ cell donor mouse (H-2/b tail), lanes 4 and 9 the $\mathrm{F} 1$ normal mother mouse accepted immunized $\mathrm{T}$ cells $\left(\mathrm{H}-2^{\mathrm{d} / \mathrm{b}}\right.$, tail) and lanes 5 and 10 the F2 baby mouse (H-2 ${ }^{\mathrm{d} / \mathrm{d}}$, spleen) alleles. M, puc19/MspI size marker. Note, in lane 5 , the mother mouse's alleles $\left(\mathrm{H}-2^{\mathrm{d} / \mathrm{b}}\right)$ can be resolved and lane 10 , the $\mathrm{H}-2^{\mathrm{d} / \mathrm{b}}$ restriction pattern (208-bp fragment and 85-bp fragment) also can be found.

\section{Discussion}

There were many reports and consideration based on the experimental and bed-side implication that the effects were many on her baby. The effect resulted in the allogenic relation was to consider to be serious to keep infant safe in the uterus. But in this article, even in a relation syngeneic, there was significant effect for her baby to suppress active immune responsiveness after delivery. This suppression was the case in rodents, mouse, rat and guinea pig in 1/6 of life-span. If it may possible to expand mouse systems into humans, the suppression is affect about until 13 years old, even transferable maternal $\mathrm{Ab}$ is effective for baby a year, after birth. Including above implications, this phenomenon is serious and worthy of future investigation, when suitable test scheme is

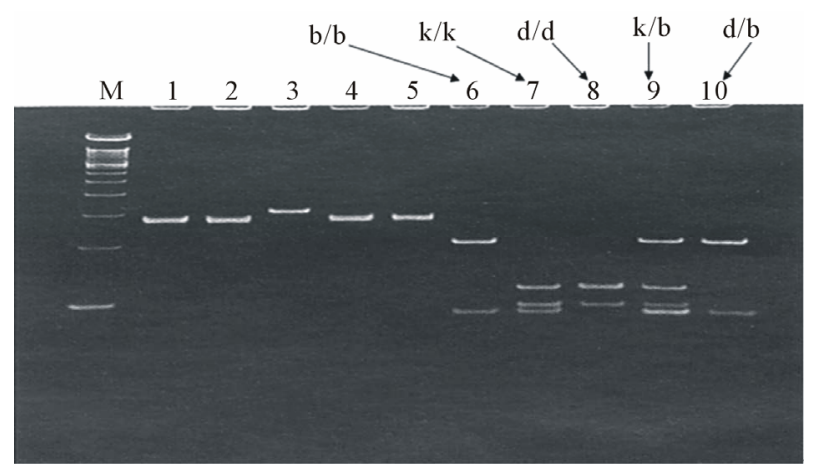

Figure 6. Polymerase chain reaction PCR) and Fnu4H I restriction pattern of three inbred and two hybrid F1) mice strain.

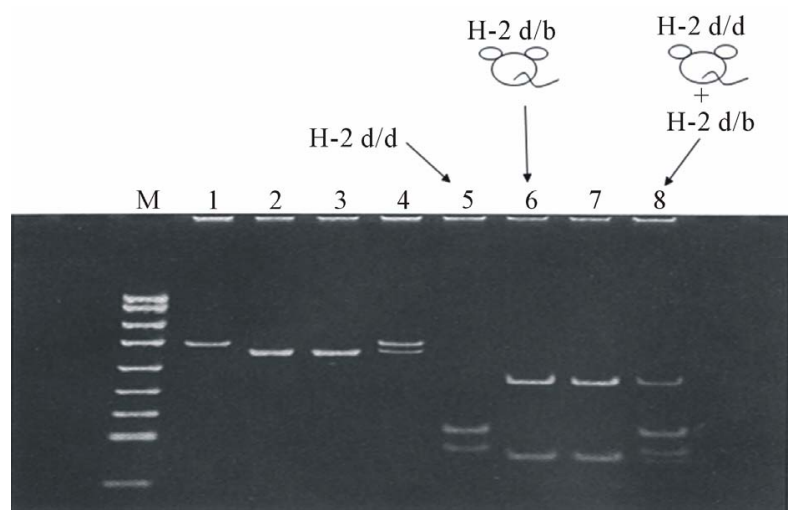

Figure 7. The $H-2^{d / b}$ allele of the engrafted $T$ cells can be found in the spleens of the $\mathrm{F} 2 \mathrm{H}-2^{\mathrm{d} / \mathrm{d}}$ baby mouse.

available in human. It is tempting to assume that two major possibilities may be involved in this suppression. First, either the SRBC or their stroma may be transferred to the foetus nor newborn. Secondly, maternal antibodies may also be related to this suppression, because the inhibitory effect on the PFC development was reciprocally related to the specific antibody levels before antigen stimulation in newborn mice. The transmission of maternal antibodies may account for the inhibition of antibody formation, as a result of discharging or masking the antigenic determinants [25]. In another system, the allogeneic new system, the maternal antibodies suppressed the infant immune responsiveness [20,22,24]. However, in our syngeneic system, the effect of allogeneic antibodies was avoided in this suppression. According to the results obtained the maternal antibody seems to affect the offspring. However, the possibility may be less likely in the light of the following observation. The offspring of the experimental group fostered by normal mother did not respond with following antigenic stimulation and no specific antibody was detected. Only from this result, there still remains a possibility that there were sufficient antibodies transferred which were not detectable by haemagglutination or haemolysin methods. They could opsonize and facilitate removal of SRBC before induction of $\mathrm{T}$ and $\mathrm{B}$ lymphocytes could occur. However, the normal offspring fostered by the stimulated mother responded well, even though the specific antibodies were detected in significant level. The experimental offspring stimulated through a pregnant mother were inhibited without any effect of postnatal serum antibodies. Moreover, from the effective timing experiment concerning gestation period and antigenic stimulation, the group of young whose mother was stimulated 3 days before fertilization were not suppressed. In this group foetuses developed in an environment filled with specific maternal transferrable antibody. However, from a dosage experiment of mother mice, the anti-SRBC PFC were induced 
by the stimulation with $10^{8}-10^{10}$ SRBC. The offspring whose mothers were stimulated with such a high dose of antigen were suppressed completely. From these results, it is reasonable to conclude that factors which were induced during antibody formation were concerned with this suppression, including specific antibody. This suppression in the young continued for at least 15 weeks after birth, indicating that the mice were suppressed for about the first one-sixth of their lives. Functional subsets of the T helper cells, Th1 and Th2, are able to be identified by the types of cytokines they produce [2,77-79]. The Th1 cells preferentially secrete IL- 2 and IFN- $\gamma$, while the Th2 cells make IL-4 and IL-5. The proportion of Th1 and Th2 T cells in the lymphoid organs determines the type of immune response in an individual $[78,79]$. While Th1 cells participate in cell mediated immune reactions the Th2 cells mediate humoral immunity and both types participate in cross regulation [76-79]. During pregnancy it has been reported that the overall direction of cytokine profiles is biased toward a type 2 response [2]. The significance of this change would be to interfere with the maternal rejection through the cell mediated immune system, of histo-compatible fetuses [2,3] by influencing the direction of maternal central lymphopoiesis as well as peripheral immune responses $[2,4,5]$. It is well known that multiparous mothers can develop high titers of cytotoxic antibody against paternally derived antigens, but this antibody does not destroy the fetus.

The findings in present studies are interesting because they show alteration in the immune response of the offspring due to immunization of the mother. Together with the results of our previous reports, we have shown that maternal $\mathrm{T}$ cells, activated in response to SRBC antigen administered during pregnancy, can direct the immune response in the offspring to a Th1 type. This may be mediated through the increased level of IFN-r secretion which could inhibit IL-4-mediated function, humoral immunity, and development of type $2 \mathrm{~T}$ helper cells [7679]. Therefore, the maternally induced suppression of antibody responses is mediated by the functional bias of $\mathrm{T}$ cells in the offspring toward a Th1 type, and as a result, antibody responses to SRBC in offspring are severely inhibited while cell mediated responses are intact [55].

The finding that the immune response in a mother can have significant effects on the immune reactivity and function in the offspring raises several important questions. One of these is the possibility that maternal immunity might foster an environment for the development of cell mediated immunity in the offspring but retard the development of the humoral immune system. A recent report has shown that in the newborn there is no defect in $\mathrm{B}$ cell function even though there is a relative inability to make antibody. The mechanism by which the newborn maintains humoral immune function is through passive antibody obtained through the placenta or through colostrum, not by making antibody in response to an antigenic challenge. This relative lack of antibody production has been attributed to an immaturity of the immune system in the infant but would appear to be due to a $\mathrm{T}$ cell control problem rather than any inherent B cell defect. Our results confirm these results and extend their significance by suggesting that there is a maternal effect on the T cell system which can result in the inhibition of antibody formation. Since the functional differentiation of $\mathrm{T}$ cell requires signaling via the $\mathrm{T}$ cell receptor (TCR) for antigen recognition $[27,56,58,75]$, the maternal effect on the functional bias reported here is probably mediated by the ligands for TCR or their carrier which are transferred from mother to fetus. We propose that the maternal effect on the functional shift to a Th1 type of response depends on either an effect on the selection of T cells specific for SRBC during ontogeny, or an effect on the functional development of mature $\mathrm{T}$ cells in the periphery. We only measured three lymphokines in this report in order to show the shift from the Th2 to the Th1 systems but there are probably other lymphokines being synthesized and released in response to an antigenic challenge. Some of these other factors can be immune suppressive (IL-10 and TGF) or inflammatory such as IL-6 and TNF, and it is possible that some of the effects that are seen on the $\mathrm{T}$ cell function in the offspring are due to other soluble factors. Furthermore, it is known that maternal $\mathrm{T}$ cells can circulate in the fetus [32] so their effects can be exerted at a very local level such as thymus and spleen, rather than necessitating the release of large amounts of factors to cross the placenta and be distributed in the fetus. These local effects may have a great importance on the differentiation and development of the newborn $\mathrm{T}$ cell population, and may be the mechanism for what we are describing in this report.

The suppressor activity could not be detected in maternal $\mathrm{CD}^{+} \mathrm{T}$ cells of SRBC-immunized pregnant mice. If the contentions that differentiation of $\mathrm{T}$ cells was biased in the offspring towards $\mathrm{CD} 4^{+} \mathrm{Th} 1$ helpers by maternal $\mathrm{T}$ cells activated during pregnancy and that the suppression of PFC response is induced by an excess of Th1 helper cells are valid, an enhancement of delayedtype hyper-sensitivity (DTH) against SRBC should have been detected, because Th1 helper $\mathrm{T}$ cells and one of their products, IFN- $\gamma$, have been shown to provide help for DTH $[2,72,76,78,79]$. However, this was not observed (that is, DTH was neither enhanced nor suppressed). Therefore a more reasonable explanation is that the suppression in offspring of the SRBC-immunized pregnant mice depends on the development of "MHC-restricted suppressor $\mathrm{T}$ cells" rather than on the non-specific 
effect of an excess of helper T cells. Furthermore, suppressor activity was found in $\mathrm{CD}^{+} \mathrm{T}$ cells of the offspring from SRBC-immunized pregnant mice but not of normal mice. Suppressor activity in normal mice was found in $\mathrm{CD} 8^{+} \mathrm{T}$ cells. Thus the profiles of suppressor activity were quite altered. Apparently, maternal $\mathrm{T}$ cells activated with SRBC during pregnancy exert a profound influence on the ontogeny of $\mathrm{T}$ cells in the offspring.

It is probably through the placenta during the gestation period that the transmission of maternal $\mathrm{T}$ cell factor(s) acts for suppression in offspring. Because it has been shown in an experiment of foster-nursing mother exchange that this maternally induced suppression is not mediated by early milk [13]. The most important point is that maternal $\mathrm{T}$ cells were activated with SRBC during the gestation period. As $\mathrm{CD}^{+} \mathrm{T}$ cells are responsible for the suppression in both the maternal and offspring immune systems, and CD4 molecules on T cells are known to assist the antigen recognitions restricted to $\mathrm{MHC}$ class II molecules [62], it might be predicted, taken together with our results of maternally induced suppression in a maternal MHC-restricted manner, that T-cell factor(s) for such suppression of the offspring's immunity are SRBC specific and MHC class II-associated molecules. It is likely that SRBC-specific $\mathrm{CD} 4^{+} \mathrm{T}$ cells undergo a unique differentiation and produce unknown, but MHC-restricted and SRBC-specific factor(s) when stimulated with SRBC under the pregnant microenvironment which is different from the non-pregnant one. Another possibility that cannot be excluded is that unknown maternal Tcell factors are produced in the immune response to SRBC during the non-gestation period and that, when transferred, they play a role in generating the repertoire of suppressor $T$ cells in the offspring only during the gestation period, because it has been reported that the environment surrounded by fetal and amniotic fluid is advantageous to the development of suppressor $\mathrm{T}$ cells and/or the suppressive activities of lymphoid cells $[6,25]$.

\section{Aspect for Prevention of Autoimmune and Avoid of Chimerism}

Autoimmune inflammatory disease is one of incurable disease such as chronic rheumatoid arthritis. The genetic and environmental factors lead to the emergence of of auto reactive $\mathrm{T}$ lymphocyte $[86,87,89-91]$. These $\mathrm{T}$ lymphocyte recognize $\mathrm{T}$ cells derived from self but without identifying the MHC and minor HC. In our series of experiment employing mice model, maternal cell are evident in her young. So we propose that MHC identical and/or non attack combination is the better to set, especially preventive aspect. The most effective prevention is to avoid risky combination whose mother does not respond immunologically inflammatory to her young. The check system of combination is the same system and grade of sensitivity that the matching test of donor/recipient systemically involved in organ transplantation such that heat, kidney transplantation. However marriage and love affair especially in human is not easy to speculate and programmed. So, the champagne have to be started to know the biological and medical sense as it is started like that AIDS champagne such as by WHO.

\section{Conclusions}

We have been investigating about the effect(s) of maternal antigenic stimulation/infection upon the active immune responses in the offspring. The results of various researchers have certainly pose significant problems as to the defense of infants against infectious agents, especially those introduced by their mothers. But we have already reported that maternal antigenic stimulation greatly suppresses the specific immune response of the offspring in a system of mouse vs. heterogonous erythrocytes and other T-dependent antigens. This suppression was antigen specific and effective on 1/6 life of rodents. The mechanisms that concerned in this suppression was not antigen administered nor antibody produced in the mother. Further discussion and significance of this biological phenomenon is proposed.

Followings are the conclusions of this presentation:

- Maternal antigenic stimulation induced complete suppression of the active immune responsiveness of her young.

- This suppression good for $1 / 6$ life of mouse for Tdependent antigens.

- Adoptive transfer of specific antibody did not induce this suppression.

- In a foster mother experiment, the stimulated foster mother did not induce suppression to the young nursed by mother in law.

- The effective cell in mother was T cell.

- The effective relation between mother to her young are MHC restricted.

- The cytokine in this suppression is IFN- $\gamma$.

- Maternal lymphocytes trafficking from mother to her young.

\section{Acknowledgment}

We are greatly appreciated to Miss Cristina Willis and Mary L. Prince for their reading and maturing this article. These works in this review were supported by Research Projects by Kanazawa Medical University (P95-16, C96-5).

\section{REFERENCES}

[1] A. K. Lefvert, "Maternal Antibodies," In: I. M. Roitt and 
P. J. Delves, Eds., Encyclopedia of Immunology, Academic Press Inc., Waltham, 1992, pp. 1038-1042.

[2] T. G. Wegmann, H. Lin, L. Guilbert and T. R. Mosmann, "Bidirectional Cytokine Interactions in the Maternal-Fetal Relationship: Is Successful Pregnancy a TH2 Phenomenon?" Immunology Today, Vol. 14, No. 7, 1993, pp. 353356. doi:10.1016/0167-5699(93)90235-D

[3] P. M. Johnson, "Fetus as Allograft," In: I. M. Roitt and P. J. Delves, Eds., Encyclopedia of Immunology, Academic Press Inc., Waltham, 1992, pp. 556-559.

[4] P. W. Kincade, K. L. Medina, G. Smithson and D. C. Scott, "Pregnancy: A Clue to Normal Regulation of B Lymphopoiesis," Immunology Today, Vol. 15, No. 11, 1994, pp. 539-544. doi:10.1016/0167-5699(94)90211-9

[5] A. G. Clarke and M. D. Kendall, "The Thymus in Pregnancy: The Interplay of Neural, Endocrine and Immune Influences," Immunology Today, Vol. 15, No. 11, 1994, pp. 545-551. doi:10.1016/0167-5699(94)90212-7

[6] Y. Miyagawa, T. Matsuoka and A. Baba, "Fetal Liver T Cell Receptor Gamma/Delta $+\mathrm{T}$ Cells as Cytotoxic T Lymphocytes Specific for Maternal Alloantigens," The Journal of Experimental Medicine, Vol. 176, No. 1, 1992, pp. 1-7. doi:10.1084/jem.176.1.1

[7] A. Tafuri, J. Alferink and P. Möller, "T Cell Awareness of Paternal Alloantigen during Pregnancy," Science, Vol. 270, No. 5236, 1995, pp. 630-633. doi:10.1126/science. 270.5236 .630

[8] A. E. Beer, R. E. Billingham and J. R. Scott, "ImmunoGenetic Aspects of Implantation, Placentation and FetoPlacental Growth Rates," Biology of Reproduction, Vol. 12, No. 1, 1975, pp. 176-189. doi:10.1095/biolreprod12.1.176

[9] D. V. Cramer, H. W. Kunz and T. J. Gill III, "Immunologic Sensitization Prior to Birth," American Journal of Obstetrics \& Gynecology, Vol. 120, No. 3, 1974, pp. 431439.

[10] R. G. Desay and W. P. Creger, "Maternofetal Passage of Leukocytes and Platelets in Man," Blood, Vol. 21, No. 6, 1963, pp. 665-673.

[11] P. K. Siiteri, F. Febres, L. E. Clemens, R. J. Chang, B. Gondos and D. Stites, "Progesterone and Maintenance of Pregnancy: Is Progesterone Nature's Immunosuppressant?" Annals of the New York Academy of Sciences, Vol. 286, No. 1, 1977, pp. 384-397. doi:10.1111/j.1749-6632.1977.tb29431.x

[12] Y. Watanabe, S. Shimizu and N. Yamaguchi, "Effect of Maternal Antigenic Stimulation on the Active Immune Responses of Their Offspring: Relationship between the Immune Reactivity of Mother Mice and the Induction of Suppression in Their Young," Scandinavian Journal of Immunology, Vol. 20, No. 4, 1984, pp. 327-332. doi:10.1111/j.1365-3083.1984.tb01009.x

[13] N. Yamaguchi, S. Shimizu and T. Saito, "The Effect of Maternal Antigenic Stimulation upon the Active Immune Responsiveness of Their Offspring," Immunology, Vol. 50, No. 2, 1983, pp. 229-238.

[14] Y. Fujii and N. Yamaguchi, "Maternal T Cells of Immu- nized Pregnant Mice Induce Immune Suppression in Their Offspring," Immunology, Vol. 77, No. 2, 1992, pp. 171-176.

[15] Y. Fuj II, A.-L. Li, H. Kohno and N. Yamaguchi, "Major Histocompatibility Complex Restriction of Maternally Induced Suppression in Young Adult Mice," Immunology, Vol. 80, No. 3, 1993, pp. 337-342.

[16] B. Kindred and G. E. Roelants, "Restricted Clonal Response to DNP in Adult Offspring of Immunized Mice: A Maternal Effect," The Journal of Immunology, Vol. 113, No. 2, 1974, pp. 445-448.

[17] B. Kindred and G. E. Roelants, "Restricted Clonal Response to DNP in Adult Offspring of Immunized Mice: A Maternal Effect," The Journal of Immunology, Vol. 113, No. 2, 1974, pp. 445-448.

[18] T. J. Gill III and H. W. Kunz, "Enhanced Antibody Response in the Offspring of Immunized Rats," The Journal of Immunology, Vol. 106, No. 1, 1971, pp. 274-275.

[19] D. R. Jacoby, L. B. Olding and M. B. A. Oldstone, "Immunologic Regulation of Fetal-Maternal Balance," Advances in Immunology, Vol. 35, 1984, pp. 157-208. doi:10.1016/S0065-2776(08)60576-3

[20] P. Stastsy, "Accelerated Graft Rejection in the Offspring of Immunized Mothers," The Journal of Immunology, Vol. 95, No. 5, 1965, pp. 929-936.

[21] D. V. Cramer, H. W. Kunz and T. J. Gill III, "Immunologic Sensitization Prior to Birth," American Journal of Obstetrics \& Gynecology, Vol. 120, No. 3, 1974, pp. 431439.

[22] J. M. Aase, G. R. Noren, D. V. Reddy and J. W. Geme Jr., "Mumps-Virus Infection in Pregnant Women and the Immunologic Response of Their Offspring," The New England Journal of Medicine, Vol. 286, No. 26, 1972, pp. 1379-1382. doi:10.1056/NEJM197206292862603

[23] B. K. Davis and T. J. Gill, "Decreased Antibody Response in the Offspring of Immunized High Responder Rats," The Journal of Immunology, Vol. 115, No. 4, 1975, pp. 1166-1168.

[24] S. Shinka, Y. Dohi, T. Komatsu, R. Natarajan and T. Amano, "Immunological Unresponsiveness in Mice. I. Immunological Unresponsiveness Induced in Embryonic Mice by Maternofetal Transfer of Human-Globulin," Biken Journal, Vol. 17, No. 2, 1974, pp. 59-72.

[25] R. Auerback and S. Clark, "Immunological Tolerance: Transmission from Mother to Offspring," Science, Vol. 189, No. 4205, 1975, pp. 811-813. doi:10.1126/science.1162355

[26] I. Iwata, S. Shimizu and N. Yamaguchi, "The Effect of Maternal Antigenic Stimulation upon the Active Immune Responsiveness of Their Offspring: Suppression Induced by Soluble Protein Antigen, Ovalbumin, in Mice," American Journal of Reproductive Immunology and Microbiology, Vol. 11, No. 2, 1986, pp. 55-58.

[27] N. K. Jerne and A. A. Nordin, "Plaque Formation in Agar by Single Antibody Producing Cells," Science, Vol. 140, No. 3565,1963 , pp. 405-408. doi:10.1126/science.140.3565.405 
[28] N. H. Jerne, A. A. Nordin and C. Henry, "The Agar Technique for Recognizing Antibody Producing Cells," In: B. Amons and H. Kaprowski, Eds., Cell-Bound Antibodies, The Wistar Institute Press, Philadelphia, 1963, pp. 109125.

[29] T. Kobayashi, J. N. Rinker and H. Koffler, "Purification and Chemical Properties of Flagellin," Archives of Biochemistry and Biophysics, Vol. 84, No. 2, 1959, pp. 342362. doi:10.1016/0003-9861(59)90598-3

[30] Y. Miura, "On the Effects of Immunization of Pregnant Mice with Soluble Protein Antigen on the Specific Immune Response of Their Offspring," Journal of the Juzen Medical Society, Vol. 92, No. 3, 1983, pp. 452-459.

[31] E. C. Golub, R. I. Mishell, W. O. Weigle and R. W. Dutton, "A Modification of the Hemolytic Plaque Assay for Use with Protein Antigens," The Journal of Immunology, Vol. 100, No. 1, 1968, pp. 133-137.

[32] C. M. M. Stern, "The Materno-Foetal Transfer of Carrier Protein Sensitivity in the Mouse," Immunology, Vol. 30, No. 3, 1976, pp. 443-448.

[33] K. Kitamura, "The Mechanism of Immunological Suppression Induced by Pretreatment with Soluble Protein Antigen Alone," Journal of the Juzen Medical Society, Vol. 93, No. 3, 1984, pp. 471-480.

[34] N. Yamaguchi, A. Hara, S. Shimizu, S. Y. Watanabe, Y. Miura and T. Saito, "The Effect of Antigenic Stimulation on the Response of Their Offspring. I. The Relationship between Immunlogical Unresponsiveness and Maternal Antibody," Journal of Kanazawa Medical University, Vol. 6, No. 4, 1981, pp. 234-240.

[35] F. N. Burnet, "The Clonal Selection Theory of Acquired Immunity," Cambridge University Press, New York, 1959.

[36] D. Gitlin and C. Koch, "On the Mechanisms of Materno Fetal Transfer of Human Albumin and G globulin in the Mouse," Journal of Clinical Investigation, Vol. 47, No. 5, 1968, pp. 1204-1209. doi:10.1172/JCI105809

[37] J. Lederberg, "Genes and Antibodies: Do Antigens Bear Instructions for Antibody Specificity or Do They Select Cell Lines That Arise by Mutation?" Science, Vol. 129, No. 3364, 1959, pp. 1649-1653. doi:10.1126/science.129.3364.1649

[38] Y. Asano and T. Tada, "Generation T Cell Repertoire: Two Distinct Mechanisms for Generation of T Suppressor Cells, T Helper Cells, and T Augmenting Cells," The Journal of Immunology, Vol. 142, No. 2, 1989, pp. 365373.

[39] M. Zoeller, “Tolerization during Pregnancy: Impact on the Development of Antigen-Specific Help and Suppression," European Journal of Immunology, Vol. 18, No. 12, 1988, pp. 1937-1943. doi:10.1002/eji.1830181211

[40] M. Zoeller, "Intrathymic T Cell Repertoire after Prenatal Trimitrobenzene-Sulfonic Acid-Treatment Cell," Immunology, Vol. 126, No. 1, 1990, pp. 31-46. doi:10.1016/0008-8749(90)90298-6

[41] H. Koshimo, H. Y. Miyazawa, Y. Shimizu and N. Yamaguchi, "Maternal Antigenic Stimulation Actively Pro- duces Suppressor Activity in Offspring," Developmental \& Comparative Immunology, Vol. 13, No. 1, 1989, pp. 79-85. doi:10.1016/0145-305X(89)90020-7

[42] C. A. Janeway Jr, "Approaching the Asymptote? Evolution and Revolution in Immunology," Cold Spring Harbor Symposia on Quantitative Biology, Vol. 54, No. 1, 1989, pp. 1-13. doi:10.1101/SQB.1989.054.01.003

[43] T. Tada, K. Hayakawa, K. Okumura and M. Taniguchi, "Coexistence of Variable Region of Immunoglobulin Heavy Chain and I Region Gene Products on AntigenSpecific Suppressor T Cells and Suppressor T Cell Factor. A Minimal Model of Functional Receptor of T Cells," Molecular Immunology, Vol. 17, No. 7, 1980, pp. 867875. doi:10.1016/0161-5890(80)90035-8

[44] T. Takemori and T. Tada, "Properties of Antigen Specific Suppressive T-Cell Factor in the Regulation of Antibody Response of the Mouse. I In Vivo Activity and Immunochemical Characterizations," The Journal of Experimental Medicine, Vol. 142, No. 5, 1975, pp. 1241-1253. doi:10.1084/jem.142.5.1241

[45] M. Taniguchi, K. Hayakawa and T. Tada, "Properties of Antigen-Specific Suppressive T-Cell Factor in the Regulation of Antibody Response of the Mouse. II. In Vitro Activity and Evidence for the I Region Gene Product," The Journal of Immunology, Vol. 116, No. 2, 1976, pp. 542-548.

[46] Y. Asano, T. Nakayama, M. Kubo, J. Yagi and T. Tada, "Epitopes Associated with MHC Restricted Site of T Cells IIII-J Epitope on MHC-Restricted T Helper Cells," The Journal of Experimental Medicine, Vol. 166, No. 6, 1987, pp. 1613-1626. doi:10.1084/jem.166.6.1613

[47] S. Shimizu, A. Hara, Y. Miura, Y. Watanabe, N. Yamaguchi, T. Saito, M. Inoue, K. Fujikawa and M. Yamamoto, "The Effect of Maternal Antigenic Stimulation on the Immune Response of Their Offspring. II. Determination of Suppressive Site," Journal of Kanazawa Medical University, Vol. 6, No. 4, 1981, pp. 241-246.

[48] G. Paul, S. Margaret, Y. F. Liew and M. M. Allan, "CD4 ${ }^{+}$ but Not $\mathrm{CD}^{+} \mathrm{T}$ Cells Are Required for the Induction of Oral Tolerance," International Immunology, Vol. 7, No. 3, 1995, pp. 501-504. doi:10.1093/intimm/7.3.501

[49] J. Samia, W. W. Hancock and L. W. Howard, "Oral Tolerance to Myelin Basic Protein and Natural Recovery from Experimental Autoimmune Encephalomyelitis Are Associated with Down regulation of Inflammatory Cytokines and Differential up Regulation of Transforming Growth Factor Beta, Interleukin 4, and Prostaglandin E Expression in the Brain," The Journal of Experimental Medicine, Vol. 176, No. 5, 1992, pp. 1355-13645. doi:10.1084/jem.176.5.1355

[50] P. Garside, M. Steel, F. Y. Liew and A. M. Mowat, "CD4 ${ }^{+}$but Not $\mathrm{CD}^{+}$T Cells Are Required for the Induction of Oral Tolerance," International Immunology, Vol. 7, No. 3, 1995, pp. 501-504. doi:10.1093/intimm/7.3.501

[51] B. R. Bloom, P. Salgame and B. Diamond, "Revisiting and Revising Suppressor T Cells," Immunology Today, Vol. 13, No. 4, 1992, pp. 131-136. doi:10.1016/0167-5699(92)90110-S 
[52] M. Feldmann and A. Basten, "The Relationship between Antigenic Structure and the Requirement for ThymusDerived Cells in the Immune Response," The Journal of Experimental Medicine, Vol. 134, No. 1, 1971, pp. 103119. doi:10.1084/jem.134.1.103

[53] J. F. A. P. Miller, G. F. Mitchell, A. J. S. Davies, H. N. Claman, E. A. Chaperon and R. B. Taylor, "Antigen Sensitive Cells, Their Source and Differentiation," Transplantation Reviews, Vol. 1, No. 1, 1969, pp. 3-42.

[54] C. Doyle and J. L. Strominger, "Interaction between CD4 and Class II MHC Molecules Mediates Cell Adhesion," Nature, Vol. 330, No. 6145, 1987, pp. 256-259. doi: $10.1038 / 330256 \mathrm{a} 0$

[55] D. C. Parker, "T Cell-Dependent B Cell Activation," Ann. Rev. Immunol, Vol. 11, No. 1, 1993, pp. 331-360. doi:10.1146/annurev.iy.11.040193.001555

[56] P. Kourilsky, J. M. Claverie, A. Prochnicka-Chalufour, A. L. Spetz-Hagberg and E. L. Larsson-Sciard, "How Important Is the Direct Recognition of Polymorphic MHC Residues by TCR in the Generation of the T-Cell Repertoire," Cold Spring Harbor Symposia on Quantitative Biology, Vol. 54, 1989, pp. 93-103.

[57] J. L. Jorgensen, P. A. Reay, E. W. Ehrich and M. M. Davis, "Molecular Components of T-Cell Recognition," Annual Review of Immunology, Vol. 10, No. 3, 1992, pp. 835-873.

[58] S. C. Jameson, K. A. Hogquist and M. J. Bevan, "Positive Selection of Thymocytes," Annual Review of Immunology, Vol. 13, No. 1, 1995, pp. 93-126. doi:10.1146/annurev.iy.13.040195.000521

[59] R. H. Schwartz, "T Lymphocyte Recognition of Antigen in Association with Gene Products of the Major Histocompatibility Complex," Annual Review of Immunology, Vol. 3, No. 1, 1985, pp. 237-261. doi:10.1146/annurev.iy.03.040185.001321

[60] A. K. Abbas, M. E. Williams, H. J. Burnstein, T. L. Chang, P. Bossu and A. H. Lichtman, "Activation and Functions of $\mathrm{CD}^{+}$T-Cell Subsets," Immunological Reviews, Vol. 123, No. 1, 1991, pp. 5-22. doi:10.1111/j.1600-065X.1991.tb00603.x

[61] S. L. Swain, L. M. Bradley, M. Croft, S. Tonkonogy, G. Atkins, A. D. Weinberg, D. D. Duncan, S. M. Henrick, R. W. Dutton and G. Huston, "Helper T-Cell Subsets: Phenotype, Function and the Role of Lymphokines in Regulating Their Development," Immunological Reviews, Vol. 123, No. 1, 1991, pp. 115-144. doi:10.1111/j.1600-065X.1991.tb00608.x

[62] C. A. Janeway, J. Rojo Jr., K. Saizawa, U. Dianzani, P. Portoles, J. T. S. Haque and B. Jones, "The Co-Receptor Function of Murine CD4," Immunological Reviews, Vol. 109, No. 1, 1989, pp. 77-92. doi:10.1111/j.1600-065X.1989.tb00020.x

[63] M. Craine, K. Semeluk, C. Lee and T. Wegmann, "Regulation of Constitutive and Lymphokine-Induced Ia Expression by Murine $\alpha$-Fetoprotein," Cellular Immunology, Vol. 118, No. 1, 1989, pp. 41-52. doi:10.1016/0008-8749(89)90356-0
[64] A. B. Peck, R. A. Murgita and H. Wigzell, "Cellular and Genetic Restrictions in the Immunoregulatory Activity of $\alpha$-Fetoprotein," The Journal of Immunology, Vol. 128, 1982, pp. 34-41.

[65] R. A. Murgita and T. B. Tomasi Jr., "Suppression of the Immune Response by $\alpha$-Fetoprotein," The Journal of Experimental Medicine, Vol. 141, No. 2, 1975, pp. 269-286. doi:10.1084/jem.141.2.269

[66] I. Roitt, "Essential Immunology," 6th Edition, Blackwell Scientific Publications, Oxford, 1988, p. 230.

[67] R. H. Schwrtz, “Acquisition of Immunological Self-Tolerance," Cell, Vol. 57, No. 7, pp. 1073-1081. doi:10.1016/0092-8674(89)90044-5

[68] C. A. Janeway Jr., J. Rojo, K. Saizawa, U. Dianzani, P. Portoles, J. Tite, S. Haque and B. Jones, "The Co-Receptor Function of Murine CD4," Immunological Reviews, Vol. 109, No. 1, 1989, pp. 77-92. doi:10.1111/j.1600-065X.1989.tb00020.x

[69] P. Kourilsky, J. M. Claverie, A. Prochnika-Chalufour, A. L. Spetz-Hagberg and E. L. Larsson-Sciard, "How Important Is the Direct Recognition of Polymorphic MHC Residues by TCR in the Generation of the T-Cell Repertoire?" Cold Spring Harbor Symposia on Quantitative Biology, Vol. 54, 1989, pp. 93-103.

doi:10.1101/SQB.1989.054.01.012

[70] N. W. Roehm, G. HRodgers, S. M. Hatfield and A. L. Glasebrook, "An Improved Colorimetric Assay for Cell Proliferation and Viability Utilizing the Tetrazolium Salt XTT," Journal of Immunological Methods, Vol. 142, No. 2, 1991, pp. 257-265. doi:10.1016/0022-1759(91)90114-U

[71] D. A. Scudiero, R. H. Shoemaker, K. D. Paul, A. Monks, S. Tierney, T. H. Nofziger, M. J. Currens, D. Seniff and M. R. Boyd, "Evaluation of Soluble Tetrazolium/Formazan Assay for Cell Growth and Drug Sensitivity in Culture Using Human and Other Tumor Cell Lines," Cancer Research, Vol. 48, No. 17, 1988, pp. 4827-4833.

[72] T. Mosmann, "Rapid Colorimetric Assay for Cellular Growth and Survival: Application to Proliferation and Cytotoxicity Assays," Journal of Immunological Methods, Vol. 65, No. 1-2, 1983, pp. 55-63. doi:10.1016/0022-1759(83)90303-4

[73] M. J. Grusby, R. S. Jonson, V. E. Papaioanou and L. H. Glimcher, "Depletion of CD4+ T-Cell in Major Histocompatibility Complex Class II-Deficient Mice," Science, Vol. 253, No. 5026, 1991, pp. 1417-142. doi:10.1126/science.1910207

[74] X.-X. Wang, B.-X. Liu, S. Katoh, S. Shimizu and N. Yamaguchi, "Maternal Immunization Affect Active Immune Response in Young-The Effect in Mhc Class-II Knockout Mouse," Journal of Reproductive Immunology, 1998.

[75] C. A. Janeway Jr., "The T Cell Receptor as a Multi Component Signalling Machine: CD4/CD8 Co-Receptors and CD45 in T Cell Activation," Annual Review of Immunology, Vol. 10, No. 1, 1992, pp. 645-674. doi:10.1146/annurev.iy.10.040192.003241 
[76] T. R. Mosmann and R. L. Coffman, "Th1 and Th2 Cells: Different Patterns of Lymphokine Secretion Lead to Different Functional Properties," Annual Review of Immunology, Vol. 7, No. 1, 1989, pp. 145-173. doi:10.1146/annurev.iy.07.040189.001045

[77] R. A. Seder and W. E. Paul, "Acquisition of Lymphokine-Producing Phenotype by $\mathrm{CD}^{+} \mathrm{T}$ Cells," Annual Review of Immunology, Vol. 12, No. 1, 1994, pp. 635673. doi:10.1146/annurev.iy.12.040194.003223

[78] P. Garside and A. M. Mowat, "Polarization of Th-Cell Responses: A Phylogenetic Consequence of Nonspecific Immune Defence," Immunology Today, Vol. 16, No. 5, 1995, pp. 220-223. doi:10.1016/0167-5699(95)80162-6

[79] A. Kelso, "Th1 and Th2 Subsets: Paradigms Lost Immunol,” Today, Vol. 16. No. 8, 1995, pp. 374-379.

[80] T. G. Wegmann, H. Lin, L. Guilbert and T. R. Mosmann, "Bidirectional Cytokine Interactions in the Maternal-Fetal Relationship Is Successful Pregnancy a TH2 Phenomenon?" Immunology Today, Vol. 14, No. 7, 1993, pp. 353356. doi:10.1016/0167-5699(93)90235-D

[81] P. Salgame, J. SAbrams, C. Clayberger, et al., "Differing Lymphokine Profiles of Functional Subsets of Human CD4 and CD8 T Cell Clones," Science, Vol. 254, No. 5029, 1991, pp. 279-282. doi:10.1126/science. 1681588

[82] H. Tomioka and H. Saito, "Characterization of Immunosuppressive Functions of Murine Peritoneal Macrophages Induced with Various Agents," Journal of Leukocyte Biology, Vol. 51, No. 1, 1992, pp. 24-31.

[83] P. G. Holt, "Immuno Prophylaxis of Atopy: Light at End of the Tunnel?" Immunology Today, Vol. 15, No. 10, 1994, pp. 484-489. doi:10.1016/0167-5699(94)90194-5

[84] G. D. Collins, F. J. Chrest and W. H. Adler, "Maternal Cell Traffic in Allogenic Embryos," Journal of Repro-

\section{Abbreviations}

DTH: Delayed type of hypersensitivity, one of the end style of immune reaction by cellular component. MHC: Major histocompatibility complex, showing individual name card made by leukocyte etc. PFC: Plague forming ductive Immunology, Vol. 2, No. 3, 1980, pp. 163-172.

[85] R. D. Barnes and J. Holliday, "The Morphological Identity of Maternal Cells in Newborn Mice," Blood, Vol. 36, No. 4, 1970, pp. 480-490.

[86] N. Yamaguchi, K. Matsui, X.-X. Wang, T. Iri and S. Shimizu, "Maternal Cells Regulated the MHC Positive Cell Development IN Young," Journal of Reproductive Immunology, 1989.

[87] Y. Fujii and N. Yamaguchi, "Maternal T Cells of Immunized Pregnant Mice Induce Immune Suppression in Their Offspring," Immunology, Vol. 77, No. 2, 1992, pp. 171-176.

[88] X.-X. Wang, A.-L. Li and Y. Ogata, "Effect of Maternal Antigenic Stimulation on the Active Immune Responsiveness of the Offspring-Possibility of Cell Transfer from the Mother to the Fetus," Journal of Kanazawa Medical University, Vol. 24, 1999, pp. 35-41.

[89] W. Wan, S. Shimizu, H. Ikawa, K. Sugiyama and N. Yamaguchi, "Maternal Cell Traffic Bounds for Immune Modulation: Tracking Maternal H-2 Alleles in Spleen of Baby Mice by DNA Fingerprinting," Immunology, Vol. 107, No. 2, 2002, pp. 261-267. doi:10.1046/j.1365-2567.2002.01499.x

[90] S. Muhannad, W. Barakat, S. Stoyanov, et al., "The HMGB1 Receptor RAGE Mediates Ischemic Brain Damage," The Journal of Neuroscience, Vol. 28, No. 46, 2008, pp. 12023-12031.

[91] J. Zotan, S. Edina, B. Balint and M. Attia, "Genetic Deficiency of Syk Protects Mice from Autoantibody-Induced Arthritis," Arthritis \& Rhematism, Vol. 62, No. 7, 2010, pp. 1899-1910. doi:10.1523/JNEUROSCI.2435-08.2008

cell, detecting method for antibody producing cell. SRBC: Sheep red blood cell, good T-dependent antigen for detecting PFC. SPC: Spleen cell, cells from central organ where antibody secret- ing cells develop. 